\title{
Rankings of International Achievement Test Performance and Economic Strength: Correlation or Conjecture?
}

\author{
CHRISTOPHER H. TIENKEN \\ Rutgers University
}

\begin{abstract}
Examining a popular political notion, this article presents results from a series of Spearman Rho calculations conducted to investigate relationships between countries' rankings on international tests of mathematics and science and future economic competitiveness as measured by the 2006 World Economic Forum's Growth Competitiveness Index (GCI). The study investigated the existence of relationships between international test rankings from three different time periods during the last 50 years of U.S. education policy development (i.e., 1957-1982, 1983-2000, and 2001-2006) and 2006 GCI ranks. It extends previous research on the topic by investigating how GCI rankings in the top 50 percent and bottom 50 percent relate to rankings on international tests for the countries that participated in each test. The study found that the relationship between ranks on international tests of mathematics and science and future economic strength is stronger among nations with lower-performing economies. Nations with strong economies, such as the United States, demonstrate a weaker, nonsignificant relationship.
\end{abstract}

Tienken, C. (2008). Rankings of International Achievement Test Performance and Economic Strength: Correlation or Conjecture? International Journal of Educatiuon Poicy and Leadership 3(4). Retrieved [DATE] from http://www.ijepl.org.

\section{Introduction}

The perceived connections between rankings on international tests of academic achievement and the economic health of the United States influenced national education policy for the past 50 years. Government reports and commissions consistently ascribe importance to the rankings of U.S. students on international tests of mathematics and science achievement. The reports in turn influence education policy at the national level.

\section{Relationship Between Rankings and Economic Growth}

The data from previous studies suggest that the relationship between student achievement rankings on international assessments of reading, mathematics, and science and a nation's future economic growth is untenable and not causal (Krueger \& Lindhal, 2001; Lewis, 1964; Ramirez, Luo, Schofer, \& Meyer, 2006). Thus, this study will investigate relationships. The reader should not interpret prior results as a denial of the existence of a link between education and economic growth.

\section{Education and Economic Growth}

The U.S. government reported that high personal education levels equated to greater lifetime monetary earnings (U.S. Census Bureau, 2000). On average, personal income has risen approximately 10 percent for every additional year of schooling. In impoverished nations, the personal income gains can be as large as 20 percent for each additional year of schooling (Mincer, 1974; Psacharopoulos \& Patrinos, 2002; van Ark, 2002). Examining the relationship between personal education levels and personal income and then drawing conclusions is one thing; however, transferring those same conclusions to international tests and national economies (Krueger \& Heckman, 2004) is quite another. The unit of analysis matters when one makes inferences about the connection of education to economics. However, the real earnings of U.S. workers with at least a bachelor's degree fell by more than 5 percent between 2000 and 2004 (Olson, 2006). Research has not shown a linear relationship between the general level of education attainment and a nation's gross domestic product (GDP) (Krueger \& Lindhal, 2001; Lewis, 1964). 
The relationship between education and national economic growth slopes upward at lower levels of education (primary grades $\mathrm{K}-4$ ), then plateaus at middle school levels (grades 5-8), then falls downward at secondary and postsecondary levels (Krueger, 1999). Increases in the general population's education level may have a greater influence on the economy in nations with nonexistent or lower-performing economies (e.g., Chad, Cameroon, Ethiopia, Kyrgyz Republic) than in highly developed economies because economically low-performing countries lack the critical mass of human capital necessary to build a high-functioning economy. In fact, countries with already high levels of education attainment see no effect on GDP when the population's education level increases. The relationship between education and a country's future economic growth is stronger in nations with lower-performing economies. It takes less of an increase in the population's level of education to influence the economy in struggling countries (Krueger, 1999). The economy needs a better-educated citizenry to grow. For example, if everyone in Chad attained an 8th grade education, there would be a direct, positive impact on the economy because the nation would have a larger collective set of more competitive skills (human capital).

Nations with strong economies (e.g., the top 22 nations on the Growth Competitiveness Index, also known as the GCI) demonstrate a weaker relationship between increases in education attainment and economic growth. Japan provides an example of this phenomenon. Japan's stock market, the Nikkei 225 Average, closed at a high of 38,915 points on December 31, 1989, and on March 1, 2006, it closed at 16,099. The 2006 closing was more than 50 percent lower than the 1989 closing, yet Japan has ranked in the Top 10 on international tests of mathematics since the 1980s. Some may argue that the Nikkei average is not a proxy measure for economic robustness, but the precipitous drop does raise questions about the supposed causal connection between international standardized test scores and economic strength.

\section{Purpose}

Those who use rankings to influence U.S. education policy voice two common arguments. They state (a) the future strength of the U.S. economy relates strongly to its rankings on international tests of education achievement, and thus (b) the U.S. should develop public education policies that will improve the rankings of its students on international tests of achievement. The purpose of this study was to investigate the claims of a strong cor- relation between future economic strength and student achievement on international tests of mathematics and science.

This study complements and adds to the knowledge dynamic in three important ways. First, it presents the results from a series of Spearman Rho calculations conducted to investigate the relationships, if any, between countries' rankings on international tests of mathematics and science and future economic competitiveness as measured by the 2006 GCI (World Economic Forum, 2006). The World Economic Forum publishes the GCI annually. Leaders from around the world recognize the GCI as a comprehensive indicator of future economic growth, and thus it is a valid index from which to investigate the existence of relationships.

Second, the study investigates the existence of relationships for international tests of mathematics and science administered in three time periods during the last 50 years of influential U.S. education policy development (1957-1982; 1983-2000; 2001-2006). The periods represent the years between Sputnik and the release of the report A Nation at Risk (National Commission on Excellence in Education, 1983), the years following A Nation at Risk and including Goals 2000 legislation, and the first four years of the No Child Left Behind (NCLB) era.

Finally, the study extends the recent work of Ramirez and colleagues (2006) by investigating how GCI rankings in the top 50 percent and bottom 50 percent relate to rankings on international tests for the countries that participated in each test.

\section{Research Questions}

Two research questions emerged from the literature base: 1. What correlations exist, if any, between countries' rankings on international tests of mathematics and science achievement and the GCI of future economic strength for the countries that participated in each test?

2. What correlations exist, if any, between a country's rankings on international tests of academic achievement and the country's GCI grouping (ranked in the top 50 percent or bottom 50 percent of the GCI)?

\section{Review of Relevant Literature}

\section{International Tests of Mathematics and Science: Between Sputnik and A Nation at Risk Report}

The International Association for the Evaluation of 
Educational Achievement (IEA) conducted three assessments following the launch of Sputnik in 1957 and prior to the release of the report A Nation at Risk (National Commission on Excellence in Education [NCEE], 1983). The First International Mathematics Study (FIMS), a test of 13-year-olds and students in their last year of secondary school, occurred in 1964. Then, the IEA collected data for the First International Science Study (FISS) in 1970-1971. The target populations for FISS included 10-year-old students, 14-year-old students, and students in their final year of secondary school. The IEA conducted the Second International Mathematics Study (SIMS) in the early 1980s and collected data on the achievement of 13-year-olds and students in their final year of secondary school. The IEA tests were not originally intended to be used to rank the performance of countries, but the preoccupation with ranks intensified after the release of A Nation of Risk (NCEST, 1992).

\section{After A Nation at Risk Report}

Following the release of the report A Nation at Risk, the IEA performed the Second International Science Study (SISS) from 1983 to 1986 and collected science achievement data on 10-year-olds, 14-year-olds, and students in their final year of secondary school. The Educational Testing Service (ETS) administered the International Assessment of Education Progress-I (IAEP-I) in 1988 and the follow-up study IAEP-II in 1991 to assess science and mathematics achievement of 13-year-old students. The IEA conducted the Third International Mathematics and Science Study (TIMSS) in 1995 and tested 9-yearolds, 13-year-olds, and students in their final year of secondary school. The IEA conducted the test again in 1999 and 2003, and TIMSS now stands for Trends in International Mathematics and Science Study.

The Organisation for Economic Co-operation and Development (OECD) administered the Program for International Student Assessment (PISA) in 2001 and 2003 to assess achievement of 15-year-old students. OECD (2003) described the aim of the mathematics PISA as, "to determine the extent to which young people have acquired the wider knowledge and skills in reading, mathematical and scientific literacy that they will need in adult life" (p. 12). Whereas the TIMSS mathematics section relies on the multiple-choice format, PISA uses open-ended questions for one-third of the assessment and multiple-choice questions for the remaining twothirds of the assessment. The mathematics sections of TIMSS and PISA differ in other ways as well. The PISA questions are longer, involving three times more words, more characters per word, and a higher Flesch-Kincaid reading level, 7.8 to 6.1 (Mullis, Martin, \& Foy, 2005; OECD, 2003).

\section{Years of Policy Influence}

Rankings on international tests of academic achievement influenced the national education goals during the past 50 years. The influence resulted in a focus on mathematics and science achievement on international tests in order to compare the performance of U.S. students to "world-class standards" as a means to ensure future economic supremacy. By 1960, driven largely by the launch of Sputnik and the National Defense Education Act of 1958, most states required that districts institute some type of internal standardized testing program to ensure that U.S. students made progress toward competing with students in the Soviet Union (Madaus, 1999).

NCEE (1983) released the report A Nation at Risk (ANAR) during the first term of the Reagan era. The report is perhaps the most commonly referenced document in the last 25 years to tout the importance of international rankings and the need for world-class standards in education. A major premise of the report is that the economic recession of the late 1970s and early 1980s, coupled with the meteoric rise of the Japanese and German economies, was caused in part by a lackluster U.S. kindergarten to 12th grade public education system, as evidenced by poor rankings on international tests of academic achievement. The report did not blame colleges and universities; national monetary, trade, or tax policies; or corporate America. The opening line of ANAR signaled the importance the commission placed on comparing the U.S. education system to those around the globe: "Our Nation is at risk. Our once unchallenged preeminence in commerce, industry, science, and technological innovation is being overtaken by competitors throughout the world" (p. 5). The NCEE noted the U.S. performance on international tests as the first indicator of risk: "International comparisons of student achievement completed a decade ago reveal that on 19 academic tests, American students were never first or second and, in comparison with other industrialized nations, were last seven times" (p. 8). The tests included the FIMS of 1964, FISS of 1970, and SIMS of 1977-1981.

The charter for the NCEE assigned eight responsibilities to the commission. The second responsibility charged the commission to "examine and to compare and contrast the curricula, standards, and expectations of 
the educational systems of several advanced countries with those of the United States" (1983, p. 39). Accordingly, the National Center on Education and the Economy supported strongly the report and its recommendation. The organization began the America's Choice School Design program in 1998 and it continues to offer forums for those interested in lobbying for policy reforms related to doing "a much better job of giving our young people the world-class skills and knowledge they need to compete in a swiftly integrating world-economy" (National Center on Education and the Economy, 2006).

The ANAR report reinvigorated the Sputnik era call for a national testing program, school choice initiatives, and vouchers, and gave a rebirth to the back-to-basics movement that helped retrench a narrow, discipline-centered, and fragmented school curriculum easily measured by commercially available standardized tests. The report brought about a renewed interest in making simplistic claims of linear, causal connections between the economic performance of the United States and its rankings on international tests.

The pursuit of world-class standards and improved international test rankings led the National Governors Association to convene a meeting in 1986 to discuss the need to reform education. The governors made two recommendations related to international rankings in the report, A Time for Results: (a) the U.S. education system should be guided by benchmarks based on international competitiveness, and (b) school choice should be implemented to increase academic performance. Former President George H.W. Bush convened the First National Education Summit in 1989 to discuss the progress made since ANAR. The summit led to the creation of the National Education Goals Panel (NEGP) two years later and President Bush's plan to "reform" education, as reported in the America 2000 plan (P.L. 102-62). A major portion of the America 2000 plan was influenced by international test rankings. The plan called for the creation of a national system of examinations to ensure that U.S. students achieve at world-class levels. One allegation made in the America 2000 report (U.S. Department of Education, 1991) was that the performance of U.S. students was "at or near the back of the pack in international comparisons" (p. 9). America 2000 called for the achievement of six broad goals. Goal 4 stated, "By the year 2000, U.S. students will be first in the world in science and mathematics achievement."

Concurrently, and driven by ANAR and the NEGP, the U.S. Department of Labor, through the Secretary's Commission on Achieving Necessary Skills (1992), known as SCANS, developed a broad set of goals aimed at developing the workforce of the future. The skills included identification, organization, planning, and allocation of resources; interpersonal skills; working in teams; gathering and using information; understanding complex interrelationships in systems; and working with technology. Interestingly, the international tests of mathematics and science do not measure those types of skills.

The America 2000 report fanned the flames of international, national, and statewide testing begun by the bellows of ANAR. Several testing and curriculum content standard amendments to the Elementary and Secondary Education Act in 1994 were influenced in part by international test rankings (Barton, 2006; Hansche, 1998). Some (Bracey, 2005; Tanner \& Tanner, 2007) labeled this apparent obsession with testing as a pandemic that continues today. The report also reinvigorated former President Ronald Reagan's prior push to open up the public education system to competition and choice on the premise it "will create the competitive climate that stimulates excellence" (U.S. Department of Education, 1991, p. 53).

Perhaps the strongest influence of international test scores on public policy was demonstrated when former President Bill Clinton supported, and the U.S. Congress passed, the Goals 2000 legislation in 1994 and codified the recommendations and goals listed in America 2000. President Clinton signed the goal of making U.S. students number one on international tests of mathematics and science into law. The law immediately began to affect federal funding to schools through the Title I program, competitive grants, state education grants, and research grants to universities and colleges. The fourth education goal stated overtly the importance of international rankings in setting national education policy: "By the year 2000 U.S. students will be first in the world in science and mathematics achievement" (NCEST, 1992, p. i). When the legislation does not make overt reference to international performance rankings, one is prompted to assume that the rankings are meaningful because the authors used repeatedly descriptive phrases such as, "world-class levels of performance" (NCEST, 1992, p. i).

Federal legislation such as Goals 2000 affected funding for competitive grants, drove research agendas at large universities and think tanks, and influenced teaching, curricula, and programs at the national and state levels. The legislation reignited the call for national standards and assessments to ensure that U.S. students would be able to compete in the global marketplace. 
The Goals 2000 legislation led to further curricular reductionism by creating a hyperinclination to use standardized tests as monitoring and punitive devices to influence teaching at the classroom level (Tanner \& Tanner, 2007). The legislation spawned policies advocating alternate schools, magnet schools, and the use of public funds to support the segmentation and further fragmentation of the $\mathrm{K}-12$ public school system. The codification of the America 2000 plan through Goals 2000 and the acceptance of international test rankings as an evaluation tool for the U.S. education system and as the predictor of economic growth helped to seemingly cement the fundamental essentialist platform in the U.S. Department of Education.

The pursuit of world-class standards intensified in 1996 with the Second National Education Summit. The state governors resolved to create internationally competitive standards and assessments to monitor implementation. Implicit in the agreement was an expectation that student performance on international achievement tests would improve. The Third National Education Summit reaffirmed the commitment of state leaders to raise standards and accountability so that all students could compete in the international marketplace. By the year 2000, 48 of the 50 states had curriculum standards and tests to monitor implementation.

International test rankings drive, in part, the renewed interest in high school reform. The U.S. Education Department used the results of the 2003 PISA mathematics section to begin high school reforms. Margaret Spellings (2005), secretary of education, stated, "The first round of No Child Left Behind reforms focused on grades 3 to 8 . And now we must finish the job in our high schools. ... And we have also recently seen that American 15-year-olds lag behind their peers across the world in math." The NCLB Act makes specific reference to improving U.S. students' rankings on international tests of mathematics and science. President George W. Bush created the National Mathematics Advisory Panel in 2006 to make policy recommendations to the president and the secretary of education. He inserted more than $\$ 250$ million into the 2007 budget to fund the Math Now program, similar in structure to the NCLB Reading First program.

The influence of international test rankings and the perceived connection to economic vitality is not confined to the political realm. International rankings influence policy decisions of some national education associations such as the National Council of Teachers of Mathematics, the National Council of Teachers of English, and the
National Science Teachers Association (NSTA). NSTA notes the influence of international achievement in the 1996 National Science Education Standards: "concerns regarding economic competitiveness stress the central importance of science and mathematics education that will allow us to keep pace with our global competitors" (National Research Council, 1996, p. 12).

\section{Documented Flaws and Limitations of International Achievement Tests}

Many variables affect a country's performance on international tests of mathematics and science. Thus, determining a causal connection between a nation's rank on an international test and future economic growth is a difficult enterprise fraught with error and myriad variables. Some common variables include (a) curricular alignment to topics tested, also known as opportunity to learn, (b) composition of the student sample of the population, (c) effect of poverty on test results, and (d) cultural view of the importance of education achievement.

\section{Opportunity to Learn}

Opportunity to earn (OTL) refers to the degree to which a country's curriculum includes or closely matches the tested topics. For example, 23 percent of the questions on the TIMSS 1999 mathematics test (for U.S. 12th grade students) presumed students had already completed calculus. Most U.S. students do not take calculus due in part to the nationwide curricular reductionism driven by federal education policies that began following Sputnik and extended through the 1960s and 1970s (Bracey, 2003; Tanner \& Tanner, 2007). Westbury (1992) found that the grade 8 portion of the SIMS was appropriate for students enrolled in algebra classes, and those students faired well on the assessment. Unfortunately, only 14 percent of the U.S. student sample took algebra prior to or at the time of the test.

The degree of curricular alignment and OTL also relate to the corresponding relationship between grade level and student age. For example, ages of students tested in their "final of year school" ranged from 17 years old in the United States to 21 years old (college seniors) in other countries (Bracey, 2003). Different structures of secondary schooling contribute to the student age differences among nations. Undoubtedly, any international assessment instrument will not reflect appropriately the curricula of any one country because there does not exist a standardized global curriculum (O'Leary, Kellaghan, Madaus, \& Beaton, 2000). 


\section{Sampling Issues}

The sample student populations of other nations generally do not compare well with the student population of the United States. The students tested in many countries represent selective populations "whereas the U.S. students represent an actual sampling of the total student population and age grouping" (Tanner \& Tanner, 2007, p. 357). Rotberg (1990) found that student selectivity correlated positively to higher results on the SIMS. The samples used by many nations to represent students in the final year of school for TIMSS would not meet the definition of random. For example, Russia tested only native speakers; Switzerland included only students in 15 of 26 cantons; Israel tested only students in Hebrewspeaking schools; and Spain restricted the sample population to Spanish-speaking schools except for students in Cataluna (Lapointe, Askew, \& Mead, 1992). Italy excluded entire provinces, such as Sicily (Bracey, 2003). In comparison, the U.S. included 98 percent of the student population in the available TIMSS sample.

\section{The Condition of Poverty}

One must consider poverty rates when discussing comparability of student samples. According to UNICEF, the U.S. ranked second highest behind Russia in the percentage of students under the age of 18 living in poverty (Bradbury \& Jäntti, 1999). Ultimate education achievement in the United States correlates to socioeconomic status (SES), and SES influences standardized test scores, further confounding the meaning of international test results (ABT Associates, 1993; Bracey, 2003; Payne \& Biddle, 1999; Rothstein, 2004). U.S. poverty rates correlate strongly with race and student achievement on standardized tests, more so than in other industrialized nations (OECD, 2005; Rotberg, 2006). For example, white U.S. students ranked second out of 29 countries on the 2000 PISA reading tests, seventh out of 30 in mathematics, and fourth out of 30 in science. Conversely, black and Hispanic students ranked 26th of 30 countries on the reading test, and 27th of 30 countries on the mathematics and science tests.

\section{Cultural Influence on Test Scores}

The cultural view of the importance of education can drive schooling practices and affect achievement. For example, in Asian countries such as Japan it is common for students to attend after-school tutoring sessions known as Juku or Cram School three to five hours per week at the parents' expense (Rotberg, 2006). Extra time after school combined with an average school year of 200 days creates an advantage of two and one-half years of schooling for students of Asian countries. The variables presented make it difficult to determine causal connections (Krueger \& Lindhal, 2001; Lewis, 1964; Ramirez et al., 2006).

\section{Index of Economic Competitiveness}

The World Economic Forum (WEF) defines competitiveness as the collection of factors, national policies, and institutions that make up the productivity of a country and influence the level of prosperity that can be achieved by an economy. The WEF produces an annual ranking of future economic competitiveness: the GCI. In producing the GCI, the WEF works to identify characteristics that determine the economic growth of 125 countries.

The WEF aims to explain the factors that contribute to the differences between economies and to identify why some economies are stronger or weaker than others. The organization calculates the GCI based on three component indexes: (a) technology innovation and adoption, (b) the integrity of public institutions, and (c) macroeconomic environment. The WEF evaluates each index based on survey data (e.g., concept of judicial independence, amount of perceived institutionalized corruption, inefficient government intervention in the economy) and data from leading economic indicators for each country.

The GCI has been a consistent predictor of U.S. economic growth. The U.S. economy, as measured by GDP growth, has been expanding for more than five years. The U.S. ranked in the top two of 125 nations on the GCI for six of the last seven years (2007 was the first year since before 2000 that the U.S. did not rank in the top two). More detail about the criteria for the GCI can be found at the Web site:

http://www.weforum.org/pdf/Global_Competitiveness_ Reports/Reports/gcr_2006/gcr2006_summary.pdf.

\section{Sample of Assessments}

The initial sample of assessments used in this study included all international assessments of mathematics and science achievement administered since the launch of Sputnik up to 2006 ( $\mathrm{N}=11$ ). Mathematics and science assessments were chosen over reading assessments because it is the rankings of U.S. students on mathematics and science assessments that receive the most policy attention in the United States. The researcher sought to analyze assessments that (a) represented the major industrial countries from various regions of the world that participated in international assessments, and (b) represented several decades so as to capture important time spans in U.S. education policymaking history. 
Assessments with fewer than 10 participating countries were excluded because they did not represent a global sample. For example, the SIMS included only five countries and several provinces from Canada and thus it was excluded from the sample. The researcher excluded the IAEP I (13-year-old students in 1988) and IAEP II (1991) because the sample population was similar to that of the TIMSS 1995 (students in last year of secondary school) and policymakers more often quote TIMSS scores as a reason to implement specific education reforms such as Goals 2000. Both student populations (IEAP and TIMSS) would have graduated high school within two to four years of each other and thus represent roughly similar time periods and similar segments of the current U.S. workforce.

The final sample included rankings and scores from assessments of mathematics and science administered in 1964 (FIMS for 13-year-olds), 1970 (FISS for 14-yearolds), 1995 (TIMSS mathematics and science sections for students in the final year of secondary school), and 2003 (PISA mathematics and science literacy sections for 15year-old students).

\section{Analysis}

The researcher used Spearman Rho calculations to examine the correlation between the participating countries' GCI ranks and rankings on the international assessments of mathematics and science. Spearman Rho is appropriate for ranked data. The researcher performed additional analyses and examined the correlations for the population of countries that participated in international assessments and ranked in the top 50 percent of the GCI and the countries at the bottom 50 percent of the GCI for the testing population. For example, the GCI ranks for the 37 participating countries on the 2003 PISA mathematics test ranged from 1st to 87th. Ranks 1-22 represented countries that had economies ranked in the top 50 percent of the GCI and that participated in the PISA 2003 ( $\mathrm{n}=18$ ), and ranks 23-87 represented countries that participated and had economies in the bottom 50 percent of the GCI ( $n=19$ ). Data from countries that did not receive a GCI rank or did not participate in an assessment were not included in the correlation analyses. Data from the FIMS and FISS were excluded from the secondary analyses because of small sample size.

\section{Results}

PISA 2003 Mathematics \& Science for 15-Year-Olds Data suggest moderate, positive (.679 and .531), significant $(\mathrm{p}<.001)$ correlations between future economic strength (GCI rank) and ranks on PISA mathematics and science literacy tests when all participating countries ( $\mathrm{N}$ = 37) are included in the analysis (see Table 1). However, the correlation weakens and almost disappears when the calculation includes only countries ranked in the top 50 percent of the GCI. The data suggest weak, positive (.215 and .191), nonsignificant ( $\mathrm{p}>$.05) correlations between GCI rank and ranks on PISA mathematics and science literacy tests for the participating countries in the top 50 percent of the GCI (see Table 2).

The correlations between GCI and test performance appear stronger for weaker economies. Data suggest moderate $(.546$ and .471$)$ significant $(p<.05)$ correlations for the participating countries ranked in the bottom 50 percent of the GCI (see Table 3).

\section{TIMSS 1995 Mathematics \& Science for Students in Final Year of Secondary School}

Data suggest moderate, positive (.671 and .703), significant $(\mathrm{p}<.001)$ correlations between GCI rank and ranks on TIMSS science and mathematics tests when all participating countries $(\mathrm{N}=21)$ are included in the analysis (see Table 4). Data suggest little, if any, negative (-.079), nonsignificant $(p>.05)$ correlation between GCI rank and rank on the TIMSS mathematics test and a weak, positive (.370), nonsignificant ( $\mathrm{p}>.05$ ) correlation between GCI rank and rank on the TIMSS science test for the participating countries ranked in the top 50 percent of the GCI for the sample (see Table 5). Furthermore, strong, positive (.724 and .733), significant $(p<.05)$ correlations exist between GCI rank and rank on TIMSS science and mathematics tests for the participating countries ranked in the bottom 50 percent of the GCI (see Table 6).

\section{FIMS 1964 for 13-Year-Olds \& FISS 1970 for 14- Year-Olds and Last Year of Secondary School}

Data suggest weak, negative (-.182 and -.118), nonsignificant ( $p>.05$ ) correlations between GCI rank and rank on the FIMS for 13-year-olds $(\mathrm{n}=12)$ and FISS for 14 -year-olds ( $n=14$ ) (see Table 7 ). Data suggest a moderate, negative (-.417), nonsignificant ( $p>.05$ ) correlation between GCI rank and rank on the FIMS for students in the last year of secondary school $(n=9)$ (see Table 8). Likewise, data suggest a weak, negative (-.145), nonsignificant ( $p>$.05) correlation between GCI rank and rank on the FISS for students in the last year of secondary school $(\mathrm{n}=11)$.

The only significant correlations observed occurred for the sample of countries ranked in the bottom 50 percent of the GCI that participated in the PISA and TIMSS 


\begin{tabular}{|c|c|c|c|c|}
\hline Country $(\mathrm{N}=37)$ & GCI Rank & $\begin{array}{l}\text { PISA Math Literacy } \\
\text { Rank/Score }\end{array}$ & $\begin{array}{l}\text { PISA Problem-Solving } \\
\text { Rank/Score }\end{array}$ & $\begin{array}{l}\text { PISA Science Literacy } \\
\text { Rank/Score }\end{array}$ \\
\hline Switzerland & 1 & $9 / 527$ & $7 / 529$ & $11 / 513$ \\
\hline Finland & 2 & $2 / 544$ & $4 / 536$ & $1 / 548$ \\
\hline Sweden & 3 & $17 / 509$ & $14 / 510$ & $14 / 506$ \\
\hline Denmark & 4 & $15 / 514$ & $12 / 514$ & $29 / 475$ \\
\hline United States & 6 & $27 / 483$ & $18 / 493$ & $21 / 491$ \\
\hline Japan & 7 & $6 / 534$ & $1 / 557$ & $1 / 548$ \\
\hline Germany & 8 & $19 / 503$ & $19 / 490$ & $17 / 502$ \\
\hline Netherlands & 9 & $4 / 538$ & DNP & $7 / 524$ \\
\hline Hong Kong_China & 11 & $1 / 550$ & DNP & $3 / 540$ \\
\hline Norway & 12 & $22 / 495$ & $16 / 499$ & $26 / 484$ \\
\hline Iceland & 14 & $14 / 515$ & $12 / 514$ & $19 / 495$ \\
\hline Canada & 16 & $7 / 532$ & $5 / 533$ & $10 / 519$ \\
\hline Austria & 17 & $18 / 506$ & $11 / 515$ & $21 / 491$ \\
\hline France & 18 & $16 / 511$ & $10 / 517$ & $12 / 511$ \\
\hline Australia & 19 & $11 / 524$ & $5 / 533$ & $5 / 525$ \\
\hline Belgium & 20 & $8 / 529$ & $9 / 520$ & $13 / 509$ \\
\hline Ireland & 21 & $19 / 503$ & $15 / 503$ & $15 / 505$ \\
\hline Luxembourg & 22 & $23 / 493$ & $28 / 446$ & $27 / 483$ \\
\hline New Zealand & 23 & $12 / 523$ & $3 / 537$ & $9 / 521$ \\
\hline Korea & 24 & $3 / 542$ & $2 / 547$ & $4 / 538$ \\
\hline Spain & 28 & $26 / 485$ & $22 / 476$ & $24 / 487$ \\
\hline Czech Rep. & 29 & $13 / 516$ & $17 / 498$ & $8 / 523$ \\
\hline Portugal & 34 & $30 / 466$ & $26 / 454$ & $30 / 468$ \\
\hline Thailand & 35 & $36 / 417$ & DNP & $34 / 429$ \\
\hline Latvia & 36 & $27 / 483$ & $24 / 463$ & $23 / 489$ \\
\hline Slovak Rep. & 37 & $21 / 498$ & DNP & $19 / 495$ \\
\hline Hungary & 41 & $24 / 490$ & $20 / 488$ & $16 / 503$ \\
\hline Italy & 42 & $30 / 466$ & $25 / 457$ & $24 / 487$ \\
\hline Greece & 47 & $32 / 445$ & $27 / 447$ & $28 / 481$ \\
\hline Poland & 48 & $24 / 490$ & $23 / 470$ & $18 / 498$ \\
\hline Indonesia & 50 & $38 / 360$ & DNP & $36 / 395$ \\
\hline Macao-China & 54 & $9 / 527$ & DNP & $5 / 525$ \\
\hline Mexico & 58 & $37 / 385$ & $29 / 387$ & $35 / 405$ \\
\hline Turkey & 59 & $34 / 423$ & DNP & $33 / 434$ \\
\hline Russia & 62 & $29 / 468$ & $21 / 478$ & $23 / 489$ \\
\hline Uruguay & 73 & $35 / 422$ & DNP & $31 / 438$ \\
\hline Serbia & 87 & $33 / 437$ & DNP & $32 / 436$ \\
\hline Spearman Rho GCI & & $.679 * *$ & $.621 * *$ & $.531^{* *}$ \\
\hline \multicolumn{5}{|c|}{$\begin{array}{l}\text { Note: Average score } 500 \text { for each test. Only countries that received a GCI rank included. DNP = Country did not participate in the test. ** } \\
=\text { Statistically significant }(p<.001)\end{array}$} \\
\hline
\end{tabular}




\begin{tabular}{|c|c|c|c|c|}
\hline Country $(n=18)$ & GCI Rank & $\begin{array}{c}\text { PISA Math Literacy } \\
\text { Rank/Score }\end{array}$ & $\begin{array}{l}\text { PISA Problem-Solving } \\
\text { Rank/Score }\end{array}$ & $\begin{array}{c}\text { PISA Science Literacy } \\
\text { Rank/Score }\end{array}$ \\
\hline Switzerland & 1 & $9 / 527$ & $7 / 529$ & $11 / 513$ \\
\hline Finland & 2 & $2 / 544$ & $4 / 536$ & $1 / 548$ \\
\hline Sweden & 3 & $17 / 509$ & $14 / 510$ & $14 / 506$ \\
\hline Denmark & 4 & $15 / 514$ & $12 / 514$ & $29 / 475$ \\
\hline United States & 6 & $27 / 483$ & $18 / 493$ & $21 / 491$ \\
\hline Japan & 7 & $6 / 534$ & $1 / 557$ & $1 / 548$ \\
\hline Germany & 8 & $19 / 503$ & $19 / 490$ & $17 / 502$ \\
\hline Netherlands & 9 & $4 / 538$ & DNP & $7 / 524$ \\
\hline Hong Kong-China & 11 & $1 / 550$ & DNP & $3 / 540$ \\
\hline Norway & 12 & $22 / 495$ & $16 / 499$ & $26 / 484$ \\
\hline Iceland & 14 & $14 / 515$ & $12 / 514$ & $19 / 495$ \\
\hline Canada & 16 & $7 / 532$ & $5 / 533$ & $10 / 519$ \\
\hline Austria & 17 & $18 / 506$ & $11 / 515$ & $21 / 491$ \\
\hline France & 18 & $16 / 511$ & $10 / 517$ & $12 / 511$ \\
\hline Australia & 19 & $11 / 524$ & $5 / 533$ & $5 / 525$ \\
\hline Belgium & 20 & $8 / 529$ & $9 / 520$ & $13 / 509$ \\
\hline Ireland & 21 & $19 / 503$ & $15 / 503$ & $15 / 505$ \\
\hline Luxembourg & 22 & $23 / 493$ & $28 / 446$ & $27 / 483$ \\
\hline Spearman Rho GCI & & $.215(.315)$ & $-.090(.759)$ & $.191(.457)$ \\
\hline
\end{tabular}

tests. The sample of countries ranked in the GCI top 50 percent for those assessments exhibited nonsignificant correlations.

\section{Conclusions}

The relationship between ranks on international tests of education achievement and future economic strength is stronger in nations that have economies grouped in the bottom $50 \%$ of the GCI rankings. In countries with economies grouped in bottom $50 \%$ of the GCI ranks it takes less of an increase in the population's average level of education completed (e.g., the average level of education increase from 9 years of formal schooling to 11 years) to improve the economy (Krueger, 1999).

For example, if everyone in Chad attained an 8th grade education, there would be a direct positive impact on the economy because the nation would have a larger collective set of more competitive skills (human capital).
Nations with strong economies (e.g., the top 22 nations on the GCI) demonstrate a weak, nonsignificant relationship between ranks on international tests of mathematics and science achievement and economic strength as measured by GCI ranks. This conclusion is congruent with the economics literature base findings that countries with already high levels of education attainment see no effect on GDP by incremental increases in the populations' levels of education (Bils \& Klenow, 1998; Krueger \& Lindhal, 2001).

The relationship between education and a country's future economic growth is stronger in nations with lower-performing economies. In high-performing nations, the education system needs the economy more than the economy needs the education system (Bils \& Klenow, 1998). Competitive and expanding labor markets in countries with strong economies drive the citizenry to seek higher levels of education (Krueger \& Solow, 


\begin{tabular}{|c|c|c|c|c|}
\hline Country $(\mathrm{n}=19)$ & GCI Rank & $\begin{array}{c}\text { PISA } 2003 \text { Math } \\
\text { Literacy Rank/Score }\end{array}$ & $\begin{array}{l}\text { PISA } 2003 \text { Problem- } \\
\text { Solving Rank/Score }\end{array}$ & $\begin{array}{l}\text { PISA } 2003 \text { Science } \\
\text { Literacy Rank/Score }\end{array}$ \\
\hline New Zealand & 23 & $12 / 523$ & $3 / 537$ & $9 / 521$ \\
\hline Korea & 24 & $3 / 542$ & $2 / 547$ & $4 / 538$ \\
\hline Spain & 28 & $26 / 485$ & $22 / 476$ & $24 / 487$ \\
\hline Czech Rep. & 29 & $13 / 516$ & $17 / 498$ & $8 / 523$ \\
\hline Portugal & 34 & $30 / 466$ & $26 / 454$ & $30 / 468$ \\
\hline Thailand & 35 & $36 / 417$ & DNP & $34 / 429$ \\
\hline Latvia & 36 & $27 / 483$ & $24 / 463$ & $23 / 489$ \\
\hline Slovak Rep. & 37 & $21 / 498$ & DNP & $19 / 495$ \\
\hline Hungary & 41 & $24 / 490$ & $20 / 488$ & $16 / 503$ \\
\hline Italy & 42 & $30 / 466$ & $25 / 457$ & $24 / 487$ \\
\hline Greece & 47 & $32 / 445$ & $27 / 447$ & $28 / 481$ \\
\hline Poland & 48 & $24 / 490$ & $23 / 470$ & $18 / 498$ \\
\hline Indonesia & 50 & $38 / 360$ & DNP & $36 / 395$ \\
\hline Macao-China & 54 & $9 / 527$ & DNP & $5 / 525$ \\
\hline Mexico & 58 & $37 / 385$ & $29 / 387$ & $35 / 405$ \\
\hline Turkey & 59 & $34 / 423$ & DNP & $33 / 434$ \\
\hline Russia & 62 & $29 / 468$ & $21 / 478$ & $23 / 489$ \\
\hline Uruguay & 73 & $35 / 422$ & DNP & $31 / 438$ \\
\hline Serbia-Montenegro & 87 & $33 / 437$ & DNP & $32 / 436$ \\
\hline Spearman Rho GCI & & $.546^{*}$ & $.601^{*}$ & $.471^{*}$ \\
\hline
\end{tabular}

2001). Harbison and Myers (1956) noted, "Education is both the seed and flower of economic development" (p. xi). Nations functioning at high economic and education levels require larger changes in the education attainment of a majority of the citizenry to have a significant influence on the economy.

Given the growing knowledge dynamic on this subject (e.g., Bils \& Klenow, 1998; Bracey, 2005; Harbison \& Myers, 1956; Krueger, 1999; Krueger \& Lindhal, 2001; Ramirez et al., 2006) policymakers and education leaders in the United States may wish to evaluate the 50year practice of developing national education policy based on the assumption that high ranks on international achievement tests lead to a strong economy.

The United States remains a global leader in overall economic strength (WEF, 2005) as measured by the GCI. The WEF ranked the U.S. economy first or second during six of the last seven years. Only Finland ranked consistently higher during that time period (ranked 1st in five of seven years). Only one Asian country, Singapore, achieved a rank in the top two (in 2000) during that time period. (The United States ranked first in 2000.) Japan ranked in the GCI top 10 only twice since 2000. Although the United States consistently ranks within the top 2 percent of all countries in the GCI sample ( $\mathrm{N}=125$ countries), it did not rank in the top 50 percent of international achievement for participating countries on the assessments sampled for this study. In the case of the United States, the data do not support the claim that a correlation exists between performance on international tests of mathematics and science and economic strength as measured by the GCI.

Many factors work in concert to contribute to the economic growth of the United States. Factors such as tax policy, trade policy, public housing and health policies, legal issues, market conditions, and the fidelity of governmental institutions can constrain or help to expand the economy. Hanushek and Woessman (2007) 


\begin{tabular}{|c|c|c|c|}
\hline Country $(\mathrm{N}=21)$ & GCI Rank & $\begin{array}{c}\text { TIMSS Science Literacy } 1995 \\
\text { Rank/Score }\end{array}$ & $\begin{array}{c}\text { TIMSS Math Literacy } 1995 \\
\text { Rank/Score }\end{array}$ \\
\hline Switzerland & 1 & $7 / 523$ & $4 / 540$ \\
\hline Sweden & 3 & $1 / 559$ & $2 / 552$ \\
\hline Denmark $^{1}$ & 4 & $11 / 509$ & $3 / 547$ \\
\hline United States $^{2}$ & 6 & $16 / 480$ & $19 / 461$ \\
\hline Germany $^{3}$ & 8 & $12 / 497$ & $13 / 495$ \\
\hline Netherlands ${ }^{1}$ & 9 & $2 / 558$ & $1 / 560$ \\
\hline Norway $^{2}$ & 12 & $4 / 544$ & $6 / 528$ \\
\hline Iceland $^{2}$ & 14 & $3 / 549$ & $5 / 534$ \\
\hline Canada $^{2}$ & 16 & $5 / 532$ & $10 / 519$ \\
\hline Austria $^{2}$ & 17 & $8 / 520$ & $11 / 518$ \\
\hline France $^{2}$ & 18 & $13 / 487$ & $7 / 523$ \\
\hline Australia $^{2}$ & 19 & $8 / 520$ & $8 / 522$ \\
\hline New Zealand & 23 & $6 / 529$ & $8 / 522$ \\
\hline Czech Rep. & 29 & $13 / 487$ & $18 / 466$ \\
\hline Slovenia $^{1}$ & 33 & $10 / 517$ & $12 / 512$ \\
\hline Lithuania & 40 & $19 / 461$ & $17 / 469$ \\
\hline Hungary & 41 & $18 / 471$ & $14 / 483$ \\
\hline Italy $^{2}$ & 42 & $17 / 475$ & $15 / 476$ \\
\hline South Africa $^{l}$ & 45 & $21 / 349$ & $21 / 356$ \\
\hline Cyprus & 46 & $20 / 448$ & $20 / 446$ \\
\hline Russia & 62 & $15 / 481$ & $16 / 471$ \\
\hline Spearman Rho GCI & & $.671 * *$ & $.703 * *$ \\
\hline
\end{tabular}

stated, "Simply providing more or higher-quality schooling may yield little in the way of economic growth" (p. 30).

\section{Commentary}

A cynic may believe that policymakers ignore the data knowingly. The Latin prefixes dis and mis are used to convey not/to deprive and less/wrong respectively. The words disinformation and misinformation convey the meanings of depriving one (the public) of the truth and providing wrong information, purposely. In national politics, critics use education disinformation and misinformation sometimes to perpetuate the merry-go-round approach to school reform in order to further political agendas.

A less cynical person may side with Socrates when evaluating the arguments regarding the alleged connection between international test-score rankings and eco- nomic growth. Socrates articulated the difference between fact and opinion by explaining that opinion resides somewhere between what is (knowledge) and what is not (ignorance). He stated, "many conventional views held by most people . . . hover somewhere between what is not and what fully is" (Plato, trans. 2003, 203d). Socrates described that those who have the eyes to seek the facts but are unable (or unwilling), even with the help of a guide, give opinions. However, it "cannot be said that they know any of the things they hold opinions about" (Plato, trans. 2003, 203e). It may be that those charged with creating and managing education policies have the capability to see and interpret the data but choose not to do so. Therefore, they give opinions (i.e., high ranks on international tests of mathematics and science bring about future economic strength) about which they know nothing. 
Table 5: Correlation Between the Participating Countries Ranked in the Top 50 percent of the GCI and Their TIMSS Science Literacy and Mathematics Literacy Ranks and Scores for Students in the Final Year of Secondary School

\begin{tabular}{|c|c|c|c|}
\hline Country $(n=10)$ & GCI Rank & $\begin{array}{c}\text { TIMSS Science Literacy } 1995 \\
\text { Rank/Score }\end{array}$ & $\begin{array}{c}\text { TIMSS Math Literacy } 1995 \\
\text { Rank/Score }\end{array}$ \\
\hline Switzerland & 1 & $7 / 523$ & $4 / 540$ \\
\hline Sweden & 3 & $1 / 559$ & $2 / 552$ \\
\hline Denmark $^{l}$ & 4 & $11 / 509$ & $3 / 547$ \\
\hline United States $^{2}$ & 6 & $16 / 480$ & $19 / 461$ \\
\hline Germany $^{3}$ & 8 & $12 / 497$ & $13 / 495$ \\
\hline Netherlands ${ }^{1}$ & 9 & $2 / 558$ & $1 / 560$ \\
\hline Norway $^{2}$ & 12 & $4 / 544$ & $6 / 528$ \\
\hline Iceland $^{2}$ & 14 & $3 / 549$ & $5 / 534$ \\
\hline Canada $^{2}$ & 16 & $5 / 532$ & $10 / 519$ \\
\hline Austria $^{2}$ & 17 & $8 / 520$ & $11 / 518$ \\
\hline Spearman Rho GCI & & $-.079(.829)$ & $.370(.293)$ \\
\hline
\end{tabular}

Table 6: Correlation Between the Participating Countries Ranked in the Bottom 50 percent of the GCI and Their TIMSS Science Literacy and Mathematics Literacy Ranks and Scores for Students in the Final Year of Secondary School

\begin{tabular}{|c|c|c|c|}
\hline Country $(\mathrm{n}=11)$ & GCI Rank & $\begin{array}{c}\text { TIMSS Science Literacy } 1995 \\
\text { Rank/Score }\end{array}$ & $\begin{array}{c}\text { TIMSS Math Literacy } 1995 \\
\text { Rank/Score }\end{array}$ \\
\hline France $^{2}$ & 18 & $13 / 487$ & $7 / 523$ \\
\hline Australia $^{2}$ & 19 & $8 / 520$ & $8 / 522$ \\
\hline New Zealand & 23 & $6 / 529$ & $8 / 522$ \\
\hline Czech Rep. & 29 & $13 / 487$ & $18 / 466$ \\
\hline Slovenia $^{1}$ & 33 & $10 / 517$ & $12 / 512$ \\
\hline Lithuania & 40 & $19 / 461$ & $17 / 469$ \\
\hline Hungary & 41 & $18 / 471$ & $14 / 483$ \\
\hline Italy $^{2}$ & 42 & $17 / 475$ & $15 / 476$ \\
\hline South Africa ${ }^{l}$ & 45 & $21 / 349$ & $21 / 356$ \\
\hline Cyprus & 46 & $20 / 448$ & $20 / 446$ \\
\hline Russia & 62 & $15 / 481$ & $16 / 471$ \\
\hline Spearman Rho GCI & & $.724 *(.05)$ & $.733 *(.05)$ \\
\hline
\end{tabular}




\begin{tabular}{|c|c|c|c|}
\hline Country $(\mathrm{N}=17)$ & GCI Rank & $\begin{array}{l}\text { FIMS 13-Year-Olds } \\
\text { Rank }^{\mathrm{a}} / \text { Items Correct }\end{array}$ & $\begin{array}{c}\text { FISS 14-Year-Olds } \\
\text { Rank }^{\mathrm{b}} / \text { Items Correct }\end{array}$ \\
\hline Finland & 2 & $4 / 26.4$ & $11 / 20.5$ \\
\hline Sweden & 3 & $12 / 15.3$ & $6 / 21.7$ \\
\hline United States & 6 & $11 / 17.8$ & $7 / 21.6$ \\
\hline Japan & 7 & $2 / 32.2$ & $1 / 31.2$ \\
\hline Germany & 8 & $5 / 25.4$ & $5 / 23.7$ \\
\hline Netherlands & 9 & $8 / 21.4$ & $13 / 17.8$ \\
\hline England & 10 & $6 / 23.8$ & $9 / 21.3$ \\
\hline Israel & 15 & $1 / 32.3$ & DNP \\
\hline France & 18 & $9 / 21.0$ & DNP \\
\hline Australia & 19 & $10 / 18.9$ & $3 / 24.6$ \\
\hline Belgium & 20 & $3 / 30.4$ & DNP \\
\hline New Zealand & 23 & DNP & $4 / 24.2$ \\
\hline Hungary & 41 & DNP & 2/29.1 \\
\hline Italy & 42 & DNP & $12 / 18.5$ \\
\hline Belgium (Fr.) & NR & DNP & $13 / 15.4$ \\
\hline Belgium (Fl.) & NR & DNP & $10 / 21.2$ \\
\hline Scotland & NR & $7 / 22.3$ & $8 / 21.4$ \\
\hline Spearman Rho GCI & & $-.182(.593)$ & $-.118(.729)$ \\
\hline
\end{tabular}

Table 8: Correlation Between GCI and the Number of Items Correct for the Participating Countries on the First International Mathematics (FIMS 1964) and Science (FISS 1970) Studies for Students in the Last Year of Secondary School for Participating Countries ${ }^{1}$

\begin{tabular}{|c|c|c|c|}
\hline Country $(\mathrm{N}=13)$ & GCI Rank & $\begin{array}{l}\text { FIMS Last Year of Secondary } \\
\text { School Rank/Items Correct }\end{array}$ & $\begin{array}{l}\text { FISS Last Year of Secondary } \\
\text { School Rank/Items Correct }\end{array}$ \\
\hline Finland & 2 & $6 / 22.5$ & $8 / 19.8$ \\
\hline Sweden & 3 & $9 / 12.6$ & 9/19.2 \\
\hline United States & 6 & $10 / 8.3$ & $14 / 13.7$ \\
\hline Japan & 7 & $3 / 25.3$ & DNP \\
\hline Germany & 8 & $1 / 27.7$ & $2 / 26.9$ \\
\hline Netherlands & 9 & $4 / 24.7$ & $4 / 23.3$ \\
\hline England & 10 & $7 / 21.4$ & $5 / 23.1$ \\
\hline France & 18 & $2 / 26.2$ & $10 / 18.3$ \\
\hline Australia & 19 & DNP & $3 / 24.7$ \\
\hline Belgium & 20 & $5 / 24.2$ & DNP \\
\hline New Zealand & 23 & DNP & $1 / 29.0$ \\
\hline Hungary & 41 & DNP & $7 / 23.0$ \\
\hline Italy & 42 & DNP & $12 / 15.9$ \\
\hline Spearman Rho GCI & & $-.417(.265)$ & $-.145(.617)$ \\
\hline
\end{tabular}




\section{References}

ABT Associations. (1993). Prospects. Boston: Author.

Barton, P. E. (2006). Needed: Higher standards for accountability. Educational Leadership, 64(3), 28-31.

Bils, M., \& Klenow, P. J. (1998). Does schooling cause growth, or the other way around? (Working Paper No. 6393). Cambridge, MA: National Bureau of Economic Research.

Bracey, G. W. (2003). April foolishness: The 20th anniversary of A Nation at Risk. Phi Delta Kappan, 84(8), 616-621.

Bracey, G. W. (2005). Research: Put out over PISA. Phi Delta Kappan, (86)10, 797-798.

Bradbury, B., \& Jäntti, M. (1999). Child poverty across industrialized nations (Innocenti Occasional Papers, Economic and Social Policy Series, no. 71). Florence, Italy: UNICEF International Child Development.

Hansche, L. N. (1998). Handbook for the development of performance standards: Meeting the requirements of Title I. Washington, DC: Department of Education and the Council for Chief State School Officers.

Hanushek, E. A., \& Woessman, L. (2007). The role of education quality for economic growth (The World Bank Policy Research Working Paper Series, No. 4122). Retrieved March 3, 2007, from http://ideas.repec.org/p/wbk/wbrwps/4122.html

Harbison, F., \& Myers, C. (Eds.). (1956). Manpower and education. New York: McGraw-Hill.

Krueger, A. B. (1999, May). Experimental estimates of education production functions. Quarterly Journal of Economics, 114(2), 497-532.

Krueger, A. B., \& Heckman, J. J. (Eds.). (2004). Inequality in America: What role for human capital policy? Cambridge, MA: MIT Press.

Krueger, A. B., \& Lindhal, M. (2001, December). Education for growth: Why and for whom? Journal of Economic Literature, 39, 1101-1136.

Krueger, A. B., \& Solow, R. (Eds.). (2001). The Roaring '90s: Can full employment be sustained? New York: Russell Sage and Century Fund.

Lapointe, A. E., Askew, J. M., \& Mead, N. A. (1992). Learning science. Princeton, NJ: Educational Testing Service.

Lewis, W. A. (1964). Secondary education and economic structure. Social and Economic Studies, (10)2, 219-232.
Madaus, G. F. (1999). The influence of testing on curriculum. In M. J. Early \& K. J. Rehage (Eds.), Issues in curriculum: A selection of chapters from past NSSE yearbooks (pp. 73-111). Chicago: National Society for the Study of Education.

Mincer, J. (1974). Schooling, earnings, and experience. New York: Columbia University Press.

Mullis, I. V. S., Martin, M. O., \& Foy, P. (2005). IEA's TIMSS 2003 international report on achievement in the mathematics cognitive domains. Chestnut Hill, MA: TIMSS \& PIRLS International Study Center, Lynch School of Education, Boston College.

National Center on Education and the Economy. (2006). NCEE's mission. Retrieved on February 22, 2007, from

http://www.ncee.org/ncee/mission/index.jsp;jsessionid $=$ aTlPcArD2pIc?setProtocol=true

National Commission on Excellence in Education (NCEE). (1983). A Nation at Risk. Washington, DC: U.S. Government Printing Office.

National Council on Education Standards and Testing (NCEST). (1992). Raising standards for American education. Washington, DC: U.S. Government Printing Office.

National Governors Association. (1986). A time for results: The governors' 1991 report on education. Washington, DC: National Governors Association, Center for Policy Research and Analysis.

National Research Council. (1996). National science education standards. Washington, DC: National Academy Press.

O'Leary, M., Kellaghan, T., Madaus, G. F., \& Beaton, A. E. (2000). Consistency of findings across international surveys of mathematics and science achievement: A comparison of IEAP2 and TIMSS.

Education Policy Analysis Archives, 8(43). Available: http://epaa.asu.edu/epaa/v8n43.html

Olson, L. (2006, March 22). Economic trends fuel push to retool school. Education Week, 25(28), pp. 1, 20, 22,24 .

Organisation for Economic Co-Operation and Development. (2005). Programme for international student assessment. Retrieved December 11, 2005, from http://www.pisa.oecd.org/pages/0,2966,en_322523 51_32235918_1_1_1_1_1,00.html 
Payne, K. J., \& Biddle, B. J. (1999, September). Poor school funding, child poverty, and mathematics achievement. Educational Researcher, 28(6), 4-13.

Plato. (2003). The Republic (R. Kamtekar, Further Reading; D. Lee, Trans.). London: Penguin Books.

Psacharopoulos, G., \& Patrinos, H. A. (2002). Returns to investment in education: A further update (World Bank Policy Research Working Paper Series, No. 2881). Retrieved November 30, 2006 from http://citeseer.ist.psu.edu/psacharopoulos02returns. html

Ramirez, F. O., Luo, X., Schofer, E., \& Meyer, J. W. (2006, November). Student achievement and national economic growth. American Journal of Education, 113(1), 1-29.

Rotberg, I. C. (1990, December). I never promised you first place. Phi Delta Kappan, 72(4), 296-303.

Rotberg, I. C. (2006). Assessment around the world. Educational Leadership, 64(3), 58-63.

Rothstein, R. (2004). Class and schools. Washington, DC: Economic Policy Institute.

Secretary's Commission on Achieving Necessary Skills, U.S. Department of Labor. (1992). What work requires of schools. Washington, DC: U.S. Department of Labor.

Spellings, M. (2005). Prepared remarks for Secretary Spellings at the Business Roundtable, February 2005. Retrieved November 8, 2006, from http://www.ed.gov/news/speeches/2005/02/02092005.html

Tanner, D., \& Tanner, L. (2007). Curriculum development: Theory into practice (4th ed.). Upper Saddle River, NJ: Pearson.

U.S. Census Bureau. (2000). Income statistics. Retrieved December 10, 2005, from http://www.census.gov/hhes/www/income/incomestats.html

U.S. Department of Education. (1991). America 2000: An education strategy. Sourcebook. Washington, DC: Author.

van Ark, B. (2002, fall). Understanding productivity and income differentials among OECD countries: A survey. The Review of Economic Performance and Social Progress, 2, 69-92. Available: http://www.csls.ca/repsp/2/bartvanark.pdf
Westbury, I. (1992). Comparing American and Japanese achievement: Is the United States really a low achiever? Educational Researcher, 21(5), 18-24.

World Economic Forum. (2005). Global competitiveness report executive summary. Retrieved December 11, 2005 from http://www.weforum.org/pdf/Gcr/GCR_05_06_Exec utive_Summary.pdf

World Economic Forum (2006). The global competitiveness report 2006-2007. Houndmills, England: Palgrave Macmillan.

IJEPL is a joint publication of the Association for Supervision and Curriculum Development, the Faculty of Education at Simon Fraser University, and the College of Education and Human Development at George Mason University. By virtue of their appearance in this open access journal, articles are free to use, with proper attribution, in educational and other non-commercial settings 90 days after initial publication. Copyright for articles published in IJEPL is retained by the authors. More information is available on the IJEPL Web site: http://www.ijepl.org 